\title{
Urotensin II: an inflammatory cytokine
}

\author{
Shui-lin Sun ${ }^{1}$ and Liang-ming Liu ${ }^{2}$ \\ 1Department of Infection, Second Affiliated Hospital of Nanchang University, Nanchang, China \\ 2Department of Infection, Songjiang Hospital Affiliated to First People's Hospital, Shanghai Jiaotong University, Shanghai, China
}

Correspondence should be addressed to L Liu: liuliangming@hotmail.com

\begin{abstract}
Urotensin II (UII) is a polypeptide molecule with neurohormone-like activity. It has been confirmed that UII is widely distributed in numerous organs of different animal species from fish to mammals, including humans. The UII receptor is orphan G-protein-coupled receptor 14, also known as UT. The tissue distribution of UII and UT is highly consistent, and their expression may be regulated by autocrine and paracrine mechanisms. In the body, UII has many physiological and pathophysiological activities, such as vasoconstrictor and vasodilatory actions, cell proliferation, pro-fibrosis, neuroendocrine activity, insulin resistance and carcinogenic and inflammatory effects, which have been recognized only in recent years. In fact, UII is involved in the process of inflammatory injury and plays a key role in the onset and development of inflammatory diseases. In this paper, we will review the roles UIl plays in inflammatory diseases.
\end{abstract}

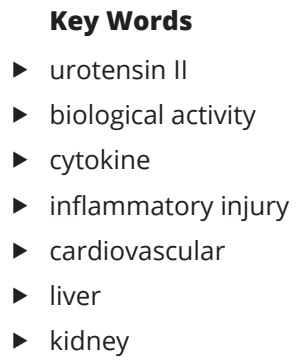

\section{Introduction}

UII is a polypeptide, the activity of which is similar to that of neurohormones. It was first isolated from the urophysis of teleost fish more than 40 years ago (Berlind 1972). UII is found not only in fish, but also in reptiles, rodents and primates, including apes and humans (Dun et al. 2001, Vaudry et al. 2010). Early studies have shown that UII has vasoconstrictor activity and is the most potent vasoconstrictor found so far, with a vasoconstrictive effect 100 times stronger than that of endothelin-1 (Ames et al. 1999, Maguire et al. 2000). However, in the case of intact endothelial cells or endothelium, UII has been found to induce vasodilatation (Ishihata et al. 2005, Lacza \& Busija 2006). UII is widely distributed in animal organs and tissues. Many organs, including the cardiovascular and central nervous systems, as well as the lung, kidney, spleen, hypophysis, adrenal gland, stomach, pancreas, ovary and liver, are found to express UII (Coulouarn et al. 1998, Nothacker et al. 1999, Ross et al. 2010). In humans, the effect of UII on peripheral vascular resistance and systemic hemodynamics is not obvious (Cheriyan et al. 2009).
In fact, UII is far from just a vasoactive molecule. It also has a variety of physiological activities (Vaudry et al. 2010) and plays a role in the onset of many diseases (Bousette \& Giaid 2006, Liu et al. 2009, Wang et al. 2011, Langham \& Kelly 2013, You et al. 2014, Garoufi et al. 2017, Li et al. 2017). In recent years, the relationship between UII and inflammation has been attracting greater attention. It has been confirmed that UII is involved in the process of inflammatory injury (Tomiyama et al. 2015, Yang et al. 2016, Ugan et al. 2018), and UII is a notable player in the development of inflammatory diseases.

\section{UII and its biological activity}

UII has variable sequence length of amino acids, predominantly residues 11-17, in different animal species. For example, there are 11 amino acid residues in human UII. At the C-terminus of the UII polypeptide, there is a covalent disulfide bridge formed by the 
CFWKYC hexapeptide cyclic conserved portion. The cyclic conserved portion is the main functional region of UII (Castel et al. 2017). The human UII gene, also known as UTS2, contains five exons. Mature UII is the result of alternative splicing of the precursor prepro-UII, the UTS2 gene expression product (Ames et al. 1999, Su et al. 2003). UII can be secreted into extracellular fluid and can enter the circulation. Under physiological conditions, plasma UII originates from the heart, liver and kidney, and its level is very low (picomolar range) (Carles et al. 2005). UII-expressing cells include endothelial cells, endocardial endothelial cells, renal epithelial cells (Maguire et al. 2004), hepatobiliary epithelial cells and Kupffer cells (Leifeld et al. 2010).

The specific receptor for UII is an orphan G-proteincoupled receptor, named GPR14 or UT. The biological activity of UII must be transduced by UT signaling, so the two are commonly referred to as the UII/UT system. In vivo, the tissue distribution of UT and UII is highly consistent (Castel et al. 2017). In most cases, the UII/UT-expressing cells are also highly consistent, showing an autocrine/paracrine regulatory mechanism (Balat et al. 2007, Wang et al. 2011). UII binds and activates UT signaling to induce intracellular calcium mobilization and increases the levels of free $\mathrm{Ca}^{2+}$ in cellular plasma (Sun et al. 2013). Increased intracellular free $\mathrm{Ca}^{2+}$ induces spastic contraction of vascular smooth muscle cells (VSMCs) (Maguire et al. 2000) and VSMC proliferation and collagen synthesis by activating the EGFR and TGF- $\beta / S m a d 2 / 3$ signaling pathways (Rodriguez-Moyano et al. 2013, Zhao et al. 2013a,b). In addition, UII also induces endothelial cell expression of eNOS and increases the release of vasodilating prostacyclin and $\mathrm{PGE}_{2}$ into the blood, resulting in vasodilatation (Zhang et al. 2003, Ishihata et al. 2005). In the heart, UII can enhance the cardiotoxic oxidative stress response (Rahimi et al. 2018) and increase PKA activity to induce the hypertrophy of neonatal cardiac myocytes (Xu et al. 2017). It also plays an important role in the development of adult hypertrophic cardiomyopathy (Jumaah et al. 2018) and rheumatic valvular disease (Elmadbouh et al. 2017). In fact, the biofunctions of UII are not only confined to the cardiovascular system, but UII also has extensive and profound effects on many tissues and cells in the body.

UII functions in the following processes: (1) cell proliferation: UII induces the proliferation of hepatic oval cells to promote liver regeneration (Yu et al. 2015) and of glomerular mesangial cells to lead to kidney diseases (Soni \& Adebiyi 2017). (2) Pro-fibrotic activities: UII promotes liver, kidney and lung fibrosis (Liu et al. 2009,
Onat et al. 2012, Chen et al. 2017) through the TGF- $\beta$ signaling pathway. (3) Neurosecretory effects: UII causes emotional imbalance by stimulating the cerebral cortex to release norepinephrine (Kawaguchi et al. 2009) and also induces the hypothalamus/pituitary axis to secrete growth hormone (Sun et al. 2013). (4) Insulin resistance: plasma levels of UII increase in diabetic patients (Totsune et al. 2003) and high levels of UII can induce insulin resistance (Li et al. 2016) and inhibit glucose uptake in skeletal muscles (Wang et al. 2013). (5) Carcinogenic effects: the expression of UII/UT is correlated with tumor progression, metastasis and prognosis (Wu et al. 2010, Balakan et al. 2014, Yu et al. 2014). UII mediates PKC- and ERK1/2dependent pro-mitogenic signaling pathways (Wang et al. 2011) and induces cell transformation to malignant tumor phenotypes (Goldberg et al. 2016). (6) Pro-inflammatory effects: the UII-mediated tissue inflammatory response has been a hot topic in recent years (Liang et al. 2013). As an inflammatory hormone-like molecule/inflammatory cytokine, UII plays a crucial role in inflammation (Liu et al. 2015a,b).

\section{Roles of UII in inflammatory diseases}

\section{Vascular injury diseases}

Inflammation of the vascular walls is critically involved in the pathogenesis of vascular injury diseases. For example, the development of atherosclerosis and essential hypertension is associated with vascular inflammation (Sun et al. 2017, Wang et al. 2018). High levels of UII not only cause both contraction of vascular smooth muscle and an increase in vascular tone, but also participate, more importantly, in chronic inflammation and injury of vessel walls.

\section{Essential hypertension}

Essential hypertension is a chronic vascular inflammatory disease (Li et al. 2005, Small et al. 2018). Experimental studies have confirmed that a large number of lymphocytes and monocytes are gathered and activated in blood vessel walls of spontaneously hypertensive rats (Schmid-Schönbein et al. 1991). In hypertensive patients, monocyte preactivation, lymphocyte proliferation and pro-inflammatory cytokine production were observed in the peripheral blood (Dorffel et al. 1999, Ni et al. 2017). Therefore, essential hypertension is fundamentally a chronic inflammatory process characterized by the activation of lymphocytes and monocytes. In this process, high arterial pressure and oxidative stress can damage 
vascular endothelium and lead to an increase in vascular permeability. Under the action of adhesion molecules such as ICAM-1 and VCAM-1, monocytes can undergo chemotaxis and adhere to the vascular walls, causing inflammatory responses (Bermudez et al. 2002). In blood vessels, UII induces the expression and secretion of ICAM-1 and VCAM-1 (Cirillo et al. 2008), likely associated with inflammatory chemotaxis in hypertension. It is also found that high levels of UII can induce monocyte chemotaxis at sites of vascular injury through the RhoA/Rho kinase pathway (Segain et al. 2007), and the pro-inflammatory cytokine IL-1 $\beta$ can enhance the chemotactic activity of UII to inflammatory cells (Segain et al. 2007). It is proven that in patients with essential hypertension, plasma UII levels are significantly higher than those in their healthy counterparts, and the degree of elevation is positively correlated with the systolic/diastolic pressure (Cheung et al. 2004). A case-control comparison study showed that UII was associated with persistently increased blood pressure and was an independent risk factor for essential hypertension (Peng et al. 2013); indeed, the degree of elevation in plasma UII could be used as an indication of the severity of essential hypertension (Zhu et al. 2015). Previous studies also showed that UII can activate leukocytes and promote these cells to release active oxygen metabolites (Djordjevic et al. 2005), causing endothelial cell damage and exfoliation as well as increasing the permeability of blood vessels (Gendron et al. 2004), a pathogenic manifestation of hypertension. These results indicate that UII may be a significant element in the process of chronic vascular inflammatory injury in essential hypertension.

\section{Atherosclerosis}

The main pathomorphological feature of atherosclerosis is that atherosclerotic plaques are formed under the intima of the arteries. These plaques are a result of the constant deposition of lipid and a variety of inflammatory cells, including monocytes/macrophages, foam cells and leukocytes, in the arterial walls (Chistiakov et al. 2018, Koelwyn et al. 2018), producing immune inflammatory responses (Autieri 2018, Miteva et al. 2018). As a disease of chronic vascular inflammation, atherosclerosis is also closely related to UII expression similar to essential hypertension (Zhao et al. 2013a,b). Studies have confirmed that UII is not significantly expressed in normal coronary arteries, but high levels of UII are found in plaques in patients with atherosclerosis (Maguire et al. 2004, Hassan et al. 2005, Loirand et al. 2008). In a study with atherosclerosis-related dementia, plasma UII and inflammatory markers IL-6 and high-sensitivity C-reactive protein (hs-CRP) levels were significantly higher in patients than those in normal controls, and the increased degree of plasma UII was positively correlated with the thickness of the maximum carotid artery intimamedia (Ban et al. 2009). Previous studies showed that in coronary atherosclerotic plaques, the UII-expressing cells are mainly endothelial cells and macrophages (Maguire et al. 2004, Loirand et al. 2008), and UII may play a role in the etiology of atherosclerosis (Hassan et al. 2005). Further classification of infiltrating white blood cells reveals that lymphocytes are also important sources of UII (Bousette et al. 2004). In addition, foam cells and smooth muscle cells can also express UII in areas of injury (Bousette et al. 2004, Maguire et al. 2004, Hassan et al. 2005, Ban et al. 2009). The specific receptor UT of UII is mainly expressed in monocytes and macrophages (Bousette et al. 2004), suggesting that monocytes or macrophages are the main effectors of UII in atherosclerotic plaque formation. Studies have confirmed that UII can, alone or in combination with IL-1 $\beta$, induce monocytes to aggregate at vascular injury sites or atherosclerotic plaques (Segain et al. 2007) and promote monocyte transformation into macrophages at the site of inflammatory injury by upregulating acyl-coenzyme A cholesterol acyltransferase 1 (ACAT-1), thereby enhancing the ability of these cells to internalize lipids (Watanabe et al. 2005, 2009). UII can also reduce cholesterol efflux from macrophages thereby promoting their conversion into the foam cell phenotype (Wang et al. 2014). In addition, macrophages and lymphocytes secrete pro-inflammatory cytokines such as IL-6, IL-1 $\beta$ and IFN- $\gamma$ in atherosclerotic plaques. These cytokines further upregulate the expression of UII and UT and accelerate the formation of atherosclerotic plaques (Birker-Robaczewska et al. 2003, Johns et al. 2004), with the autocrine/paracrine effects of macrophage UII significantly increasing macrophage-positive areas (Zhao et al. 2015) and destabilizing atherosclerotic plaques (Li et al. 2014, Albanese et al. 2016). Reports in recent years show that UII can induce the expression and secretion of various inflammatory cytokines, such as MCP- 1 and TGF- $\beta$, causing arterial inflammatory injury (You et al. 2012, Zhao et al. 2014). UII can also induce apolipoprotein apoB expression and suppress apoA-1 expression, promoting the development of atherosclerosis (Khoshi et al. 2014). In addition, UII can promote the proliferation of VSMC to lead to vascular stenosis and remodeling, by activating the ERK/ROS signaling pathway in atherosclerotic lesions (Kim et al. 2017). UII receptor antagonist, urantide, has the ability to protect against atherosclerosis in the rat 
model (Zhao et al. 2013a,b). Therefore, UII has extensive and profound effects on the occurrence and development of atherosclerosis.

\section{Heart failure}

Heart failure is a chronic inflammatory injury disease of the myocardium. Immune inflammation greatly contributes to the pathogenesis of heart failure (Zhang et al. 2017, Yu \& Feng 2018). During this process, many cytokines and inflammatory molecules are expressed and released, such as TNF- $\alpha$, IL-1 $\beta$ and IL- 6 , adhesion molecules and CRP (Torre-Amione et al. 2000, Alonso-Martínez et al. 2002, Deten et al. 2003). UII can promote the expression and secretion of IL-6 from cardiac myocytes (Johns et al. 2004). IL-6 is a cytokine with significant pro-inflammatory effects (Lichtman et al. 1998) and is increased more than fourfold in H9c2 myocardial cells after $6 \mathrm{~h}$ of UII stimulation $(10 \mathrm{nM})$. This induction is equivalent to the expression levels of IL-6 protein produced by stimulation with $10 \mathrm{ng} / \mathrm{mL}$ LPS in cardiac myocytes (Johns et al. 2004). Indeed, it has been found that plasma UII levels are significantly elevated in patients with acute and chronic heart failure (Jani et al. 2013). In addition, high levels of UII and its receptor UT are observed in myocardial tissues in patients with heart failure (Douglas et al. 2002). UII receptor antagonists can significantly reduce UIIinduced fibrosis and cell hypertrophy in cardiomyocytes, as well as heart dysfunction in experimental heart failure (Park et al. 2016, Oh et al. 2017). In a rat model of heart failure, the expression levels of UII, UT, IL- $1 \beta$ and IL- 6 are prominently increased in ventricular myocytes in parallel to the duration and degree of myocardial injury (Johns et al. 2004). At the same time, UII, through IL-6, acts on its receptor gp130 to activate Jak/STAT signaling, resulting in myocardiocyte hypertrophy and ventricular remodeling (Yamauichi-Takihara \& Kishimoto 2000). At the same time, UII inhibits the proliferation of endogenous cardiac side population stem cells through the JNK pathway (Chen et al. 2014), thus aggravating heart failure and making it difficult to reverse.

\section{Chronic renal disease}

Most chronic kidney diseases (CKD), including glomerulonephritis, renal tubular diseases and renal fibrosis, are inflammation-related diseases (RodriguezMoyano et al. 2013, Sun et al. 2013). Innate immune inflammatory responses are considered to be the main pathophysiological mechanism of kidney diseases and kidney injury (Wang \& Zhang 2017). Macrophages are involved in the occurrence and development of various CKD (Guiteras et al. 2016). During the disease process, TLR4 signaling is activated, and many pro-inflammatory cytokines such as TNF- $\alpha$, IL- 6 and IL-17A are released (Cortvrindt et al. 2017, Garibotto et al. 2017, Su et al. 2017). Immunohistochemistry and mRNA assays show that the kidney expresses UII and its receptor UT (Song et al. 2006). In a normal human kidney, UII is mainly expressed in the renal tubular epithelial cells, while the glomerular endothelial cells exhibit only focal expression (Shenouda et al. 2002), and circulating UII is low and difficult to detect $(<50 \mathrm{pg} / \mathrm{mL})$ (Matsushita et al. 2001). In patients with chronic glomerulonephritis, abundant UII can be seen in the glomerular basement membrane, mesangial membrane and glomerular capsule (Balat et al. 2007). The glomerular crescent, which is composed of glomerular capsule epithelial cells and infiltrating macrophages, is also found to have high UII expression in CKD patients (Balat et al. 2007, Balat 2010). It is worth noting that crescentic formation is a sign of severe glomerular injury and rapid progression of disease ( $\mathrm{Li} \&$ Chen 2013). In addition, plasma UII levels increased significantly in patients with CKD (Ashton 2006), and higher levels of UII were found in CKD patients with metabolic acidosis (Garoufi et al. 2017). In patients with chronic kidney failure, urinary UII is also notably increased (Ashton 2006), with the concentration of urinary UII 1650 times higher than that of blood (Song et al. 2006). These data suggest the importance of UII in the pathogenesis of kidney diseases. Studies have shown that UII can induce the release of inflammatory mediators via paracrine or autocrine modes during the deposition of antigen-antibody complexes, triggering and amplifying the inflammatory responses to aggravate renal damage (Balat et al. 2007). In CKD, an increase in UII secretion is an early event, followed by an elevation in oxidative stress parameters (Tabur et al. 2015) and the expression of the cytokine TGF- $\beta$ in renal tubular epithelial cells (Cernaro et al. 2017). UII-induced oxidative stress, cytokine release and inflammation are like a 'devil's triangle' (Balat \& Büyükçelik 2012), which promotes and aggravates the inflammatory damage of CKD.

\section{Acute hepatic failure}

Acute liver failure (ALF) is an immune inflammatory injury disease. Cascading release of inflammatory cytokines is the main pathophysiological mechanism of the development of ALF (Yoshimura et al. 2007, Liu et al. 2009). Mononuclear phagocytes, especially hepatic 
Kupffer cells, are thought to be the main cell source for the production of inflammatory cytokines, including IFN- $\gamma$, IL-6 and TNF- $\alpha$ (Ramadori \& Armbrust 2001, Zhang et al. 2003). It has been demonstrated that in patients with ALF, there are not only a large number of inflammatory cytokines in the circulation, but also high levels of UII and its receptor UT in the liver, and the increased plasma levels of UII are closely correlated with the elevated levels of the inflammatory cytokines IFN- $\gamma$ and IL-6 (Leifeld et al. 2010). In lipopolysaccharide (LPS)/D-galactosamine (D-GalN)-induced ALF, the expression and activity of hepatic UII and UT were significantly upregulated (Liang et al. 2013). The UII receptor antagonist urantide inhibited LPS/D-GalN-induced UII/UT liver expression in ALF rats, and at the same time, it protected experimental rats from death and hepatic inflammatory injury caused by LPS/D-GalN attack by blocking UII signal transduction (Liang et al. 2013). It has further been confirmed that in ALF, UII mediates hepatic immune inflammatory injury mainly by activating the TLR4 signaling pathway and the release of its downstream pro-inflammatory cytokines, including TNF- $\alpha$ and IL-1 $\beta$ (Liang et al. 2013). It is known that hepatic parenchymal cells do not express UII and UT, with the UII/UT-expressing cells mainly comprising innate immune cells, such as Kupffer cells, vascular endothelial cells and bile duct epithelial cells in the liver in ALF (Leifeld et al. 2010, Liang et al. 2013). In primary Kupffer cells, LPS stimulation markedly induces the production of UII/UT, TNF- $\alpha$ and IL-1 $\beta$; after urantide pretreatment, the expression and secretion of TNF- $\alpha$ and IL- $1 \beta$ were significantly downregulated, as was the release of UII (Liu et al. 2015a,b). These data suggest that autocrine/paracrine regulatory mechanisms of Kupffer cell UII can establish a positive feedback loop, which may induce cascading release of pro-inflammatory cytokines and gradually enhance intrahepatic inflammatory reactions. In a study of the time-dependent secretion of plasma UII, high levels of plasma UII are demonstrated to be an earlier event than TNF- $\alpha$ and IL-1 $\beta$ production in ALF (Liu et al. 2015a,b). This result further suggests that UII may be the trigger for the inflammatory reaction in the liver and may be crucial to the pathogenesis of ALF by initiating early production and release of inflammatory cytokines.

\section{Other inflammatory diseases}

In addition to the diseases mentioned above, UII has a prominent effect on the development of many other inflammatory diseases. Studies have confirmed that UII and its signaling system mediate carrageenan-induced inflammatory responses, and pretreatment with the UII receptor antagonist reduces tissue inflammation and decreases TNF- $\alpha$ and IL-6 expression (Cadirci et al. 2016). UII also mediates vascular inflammation and vascular remodeling, both of which are inhibited by UII receptor antagonists through their blockade of ERK1/2 and NF-kB signaling pathways in experimental pulmonary hypertension (Lee et al. 2016). In vivo and in vitro studies of colitis have also confirmed that the UII/UT system mediates tissue inflammatory responses through NF- $\mathrm{kB}$ signaling (Yang et al. 2016). In addition, UII expression increases in patients with cancer (Liu et al. 2016a,b), diabetes (He et al. 2015) and metabolic syndrome (Barrette \& Schwertani 2012). In a sense, these diseases are also the result of chronic local or systemic inflammation. The increased expression and secretion of UII in these patients may have a key impact on the inflammatory damage induced in these diseases.

\section{Pro-inflammatory mechanisms of UII}

Inflammatory responses involve innate immune cells such as macrophages, endothelial cells and others. Exogenous (Borlak et al. 2016) and endogenous (Wheeler 2003) stimuli can induce the activation of these cells, resulting in the release of pro-inflammatory cytokines that cause tissue inflammation and injury (Tsutsui \& Nishiguchi 2014). In this process, injurious stimuli, including pathogens and toxins (i.e., LPS), activate the pattern recognition receptor TLR4 on the cell surface. Through adaptor proteins, TLR4 activates two important cellular signaling pathways - the MyD88-dependent and TRIF-dependent (or MyD88-independent) pathways (Liu et al. 2015a,b). After activation, the MyD88-dependent pathway induces the expression and release of proinflammatory cytokines such as TNF- $\alpha$, IL-1 $\beta$ and IL-6 through the p38 MAPK and NF-kB signaling pathways (Liu et al. 2015a,b). TRIF signaling induces the production of type 1 interferons such as IFN- $\beta$ through the activation of interferon regulatory factor 3 (IRF3) to promote an innate immune response (Tsutsui \& Nishiguchi 2014).

UII and its receptor signaling system mediate the production of pro-inflammatory mediators including TNF- $\alpha$, IL- $1 \beta$, IFN- $\gamma$, IL-8 and leukotriene C4 and have a positive effect on the TLR4 downstream MyD88-dependent signaling pathway (Liang et al. 2013, Dong et al. 2013, Lee et al. 2014). It has been demonstrated that this signaling system upregulates the levels of phosphorylated nuclear p38 MAPK protein (Liu et al. 2015a,b). p38 is a MAPK 
family member and is activated by phosphorylation in the nucleus, thereby inducing the transcription and expression of pro-inflammatory cytokines (Lee et al. 1994). The UII/UT system also activates the NF-kB inflammatory pathway by promoting nuclear translocation and DNAbinding activity of the p65 subunit (Liu et al. 2015a,b), which induces the transcription and expression of various inflammation-related genes, that is, the pro-inflammatory cytokines TNF- $\alpha$ and IL-1 $\beta$ (Baldwin 1996). In addition, the UII/UT system can activate the MyD88-independent signal IRF3 by inducing IRF3 gene transcription and nuclear translocation of the protein (Liu et al. 2016a,b). Previous reports have shown that the IRF3 molecule increases the levels of TNF- $\alpha$ and IL- $1 \beta$ protein (a posttranscriptional regulation) and promotes inflammatory reactions by upregulating IFN- $\beta$ without affecting p38 MAPK and NF-kB activity (Liu et al. 2016a,b) (Fig. 1). Therefore, UII may be the unifying factor underlying the molecular basis of the innate immune and inflammatory responses.

\section{Last but not least}

Inflammatory injury is closely related to immune responses in the body. Indeed, innate immune cells and recruited inflammatory cells, like neutrophils and lymphocytes, are involved in the development of tissue inflammatory injury. Insight into the inflammatory injury and immune role of the small polypeptide UII has shown remarkable progress in recent years. In fact, most tissue inflammation in the body involves UII and its signaling system, and UII is a common molecular basis for these tissues to produce inflammatory reactions.

In the process of inflammation, injury factors stimulate the expression and secretion of UII from innate immune cells (including vascular endothelial cells and macrophages) in local tissues. The release of UII, through autocrine/paracrine effects, stimulates the further upregulation of UII expression and induces cascading release of pro-inflammatory cytokines, including TNF- $\alpha$, IL-1 $\beta$ and so on. At the same time, UII serves as an inflammatory chemotactic molecule to recruit circulating UT-expressing inflammatory cells, such as monocytes and macrophages, to local lesions, thereby aggravating inflammatory damage to tissues (Segain et al. 2007). In addition, UII can be secreted into the blood from the inflamed organs, which may produce inflammatory hormone-like effects on distant organs and even induce systemic inflammatory responses.

However, the mechanism of the UII-mediated inflammatory injury response is still not fully understood. As a key molecule in inflammatory responses, UII has gained more and more attention from many scholars. By measuring UII/UT levels, investigators can monitor inflammation in the injured area, including the

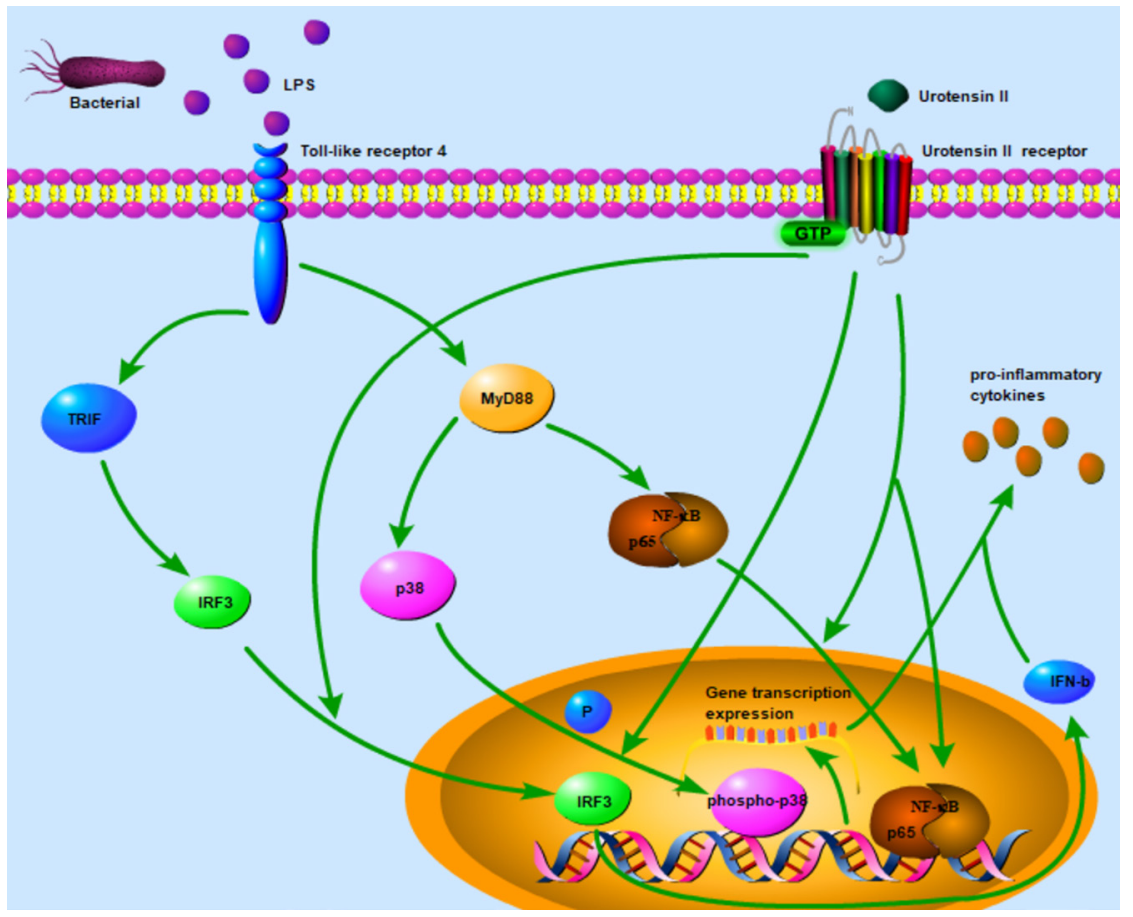

Figure 1

UII pro-inflammatory mechanisms: LPS binding to TLR4 initiates MyD88-dependent and -independent (or TRIF) signaling pathways to induce the production of pro-inflammatory cytokines by activating NF-кB and p38 MAPK and IRF3, respectively. Association of the UII polypeptide with its receptor UT upregulates the levels of nuclear p38 MAPK phosphorylated protein and promotes nuclear transfer and DNA-binding activity of the NF-кB p65 subunit, leading to gene expression of pro-inflammatory cytokines. In parallel, the UII/UT system activates IRF3-IFN- $\beta$ signaling to increase TNF- $\alpha$ and IL-1 $\beta$ protein levels. A full color version of this figure is available at https://doi.org/10.1530/JOE-18-0505. 
inflammatory microenvironment of tumors (Zhou et al. 2012) and sepsis-induced damage (Cadirci et al. 2018); these levels may even serve as a way to judge the degree of inflammation. In recent years, UII and its signaling system have been used as targets for drug therapy for various inflammatory diseases. In animal experiments, UII receptor antagonists are used to block signal transduction of the UII/UT system, achieving satisfactory anti-inflammatory results. However, the research and development of drugs has not yet started in the area of human disease treatment. In view of the wide range of diseases related to inflammation, breakthroughs in inflammatory therapy research will bring revolutionary progress in clinical disease treatment in the future. For example, by inhibiting the inflammatory responses induced by UII, it may be possible to treat heart failure, liver failure, chronic nephritis and diabetic complications. It may even be possible to treat metabolic syndrome caused by obesity as well as to prevent and treat cancer.

\section{Declaration of interest}

The authors declare that there is no conflict of interest that could be perceived as prejudicing the impartiality of this review.

\section{Funding}

This work was supported by the National Natural Science Foundation of China (No. 81770612 , No. 81070357 and No. 30660066).

\section{Acknowledgement}

The authors thank Yi-tong Liu, Shanghai International Studies University, for proofreading the manuscript.

\section{References}

Albanese I, Daskalopoulou SS, Yu B, You Z, Genest J, Alsheikh-Ali A \& Schwertani AG 2016 The urotensin II system and carotid atherosclerosis: a role in vascular calcification. Frontiers in Pharmacology 7 149. (https://doi.org/10.3389/fphar.2016.00149)

Alonso-Martínez JL, Llorente-Diez B, Echegaray-Agara M, Olaz-Preciado F, Urbieta-Echezarreta M \& González-Arencibia C 2002 C-reactive protein as a predictor of improvement and readmission in heart failure. European Journal of Heart Failure 4 331-336. (https://doi. org/10.1016/S1388-9842(02)00021-1)

Ames RS, Sarau HM, Chambers JK, Willette RN, Aiyar NV, Romanic AM, Louden CS, Foley JJ, Sauermelch CF, Coatney RW, et al. 1999 Human urotensin-II is a potent vasoconstrictor and agonist for the orphan receptor GPR14. Nature 401 282-286. (https://doi.org/10.1038/45809)

Ashton N 2006 Renal and vascular actions of urotensin II. Kidney International 70 624-629. (https://doi.org/10.1038/sj.ki.5001621)

Autieri MV 2018 IL-19 and other IL-20 family member cytokines in vascular inflammatory diseases. Frontiers in Immunology 9700. (https://doi.org/10.3389/fimmu.2018.00700)
Balakan O, Kalender ME, Suner A, Cengiz B, Oztuzcu S, Bayraktar R, Borazan E, Babacan T \& Camci C 2014 The relationship between urotensin II and its receptor and the clinicopathological parameters of breast cancer. Medical Science Monitor 20 1419-1425. (https://doi. org/10.12659/MSM.890459)

Balat A 2010 Kidney is in trouble with mediators. Bosnian Journal of Basic Medical Sciences 10 (Supplement 1) S29-S36. (https://doi. org/10.17305/bjbms.2010.2643)

Balat A \& Büyükçelik M 2012 Urotensin-II: more than a mediator for kidney. International Journal of Nephrology 2012 249790. (https://doi. org/10.1155/2012/249790).

Balat A, Karakök M, Yilmaz K \& Kibar Y 2007 Urotensin-II immunoreactivity in children with chronic glomerulonephritis. Renal Failure 29 573-578. (https://doi.org/10.1080/08860220701392108)

Baldwin AS 1996 The NF-kappaB and I kappa-B proteins: new discoveries and insights. Annual Review of Immunology 14 649-683. (https://doi. org/10.1146/annurev.immunol.14.1.649)

Ban Y, Watanabe T, Suguro T, Matsuyama TA, Iso Y, Sakai T, Sato R, Idei T, Nakano Y, Ota H, et al. 2009 Increased plasma urotensin II and carotid atherosclerosis are associated with vascular dementia. Journal of Atherosclerosis and Thrombosis 16 179-187. (https://doi.org/10.5551/ jat.E608)

Barrette PO \& Schwertani AG 2012 A closer look at the role of urotensin II in the metabolic syndrome. Frontiers in Endocrinology 3165. (https://doi.org/10.3389/fendo.2012.00165)

Berlind A 1972 Teleost caudal neurosecretory system: release of urotensin II from isolated urophyses. General and Comparative Endocrinology 18 557-560. (https://doi.org/10.1016/0016-6480(72)90036-6)

Bermudez EA, Rifai N, Buring J, Manson JE \& Ridker PM 2002 Interrelationships among circulating interleukin-6, C-reactive protein and traditional cardiovascular risk factors in women. Arteriosclerosis, Thrombosis, and Vascular Biology 22 1668-1673. (https://doi. org/10.1161/01.ATV.0000029781.31325.66)

Birker-Robaczewska M, Boukhadra C, Studer R, Mueller C, Binkert C \& Nayler O 2003 The expression of urotensin II receptor (U2R) is up-regulated by interferon-gamma. Journal of Receptor and Signal Transduction Research 23 289-305. (https://doi.org/10.1081/RRS120026972)

Borlak J, Langer F, Spanel R, Schöndorfer G \& Dittrich C 2016 Immune-mediated liver injury of the cancer therapeutic antibody catumaxomab targeting EpCAM, CD3 and Fc $\gamma$ receptors. Oncotarget 7 28059-28074.

Bousette N \& Giaid A 2006 Urotensin-II and cardiovascular diseases. Current Hypertension Reports 8 479-483. (https://doi.org/10.1007/ s11906-006-0026-7)

Bousette N, Patel L, Douglas SA, Ohlstein EH \& Giaid A 2004 Increased expression of urotensin II and its cognate receptor GPR14 in atherosclerotic lesions of the human aorta. Atherosclerosis $\mathbf{1 7 6}$ 117-123. (https://doi.org/10.1016/j.atherosclerosis.2004.03.023)

Cadirci E, Halici Z, Yayla M, Toktay E, Bayir Y, Karakus E, Topcu A, Buyuk B \& Albayrak A 2016 Blocking of urotensin receptors as new target for treatment of carrageenan induced inflammation in rats. Peptides 82 35-43. (https://doi.org/10.1016/j. peptides.2016.05.006)

Cadirci E, Ugan RA, Dincer B, Gundogdu B, Cinar I, Akpinar E \& Halici Z 2018 Urotensin receptors as a new target for CLP induced septic lung injury in mice. Naunyn-Schmiedeberg's Archives of Pharmacology [epub]. (https://doi.org/10.1007/s00210-018-1571-8)

Carles CJ, Rademaker MT, Richards AM \& Yandle TG 2005 Urotensin II: evidence for cardiac, hepatic and renal production. Peptides $\mathbf{2 6}$ 2211-2214. (https://doi.org/10.1016/j.peptides.2005.03.043)

Castel H, Deskues L, Joubert JE, Tonon MC, Prézeau L, Chabbert M, Morin F \& Gandolfo P 2017 The G protein-coupled receptor UT of the neuropeptide urotensin II displays structural and functional chemokine features. Frontiers in Endocrinology 8 76. (https://doi. org/10.3389/fendo.2017.00076) https://joe.bioscientifica.com

https://doi.org/10.1530/JOE-18-0505 (c) 2019 Society for Endocrinology Published by Bioscientifica Ltd. Printed in Great Britain 
Cernaro V, Medici MA, Bianco F, Santoro D, Lacquaniti A, Romeo A, Lucisano S, Buemi A \& Buemi M 2017 Opposite actions of urotensin II and relaxin-2 on cellular expression of fibronectin in renal fibrosis: a preliminary experimental study. Clinical and Experimental Pharmacology and Physiology 44 1069-1071. (https://doi. org/10.1111/1440-1681.12798)

Chen Z, Xu J, Ye Y, Li Y, Gong H, Zhang G, Wu J, Jia J, Liu M, Chen Y et al. 2014 Urotensin II inhibited the proliferation of cardiac side population cells in mice during pressure overload by JNK-LRP6 signaling. Journal of Cellular and Molecular Medicine 18 852-862. (https://doi.org/10.1111/jcmm.12230)

Chen S, Wang Y \& Wan Y 2017 Urotensin II enhances transforming growth factor- $\beta 1$ expression and secretion in the kidney during aristolochic acid nephropathy. Molecular Medicine Reports 16 6904-6909. (https://doi.org/10.3892/mmr.2017.7424)

Cheriyan J, Burton TJ, Bradley TJ, Wallace SML, Mäki-Petäjä KM, Mackenzie IS, McEniery CM, Brown J \& Wilkinson IB 2009 The effects of urotensin II and urantide on forearm blood flow and systemic haemodynamics in humans. British Journal of Clinical Pharmacology 68 518-523. (https://doi.org/10.1111/j.1365-2125.2009.03475.x)

Cheung BM, Leung R, Man YB \& Wong LY 2004 Plasma concentration of urotensin II is raised in hypertension. Journal of Hypertension 22 1341-1344. (https://doi.org/10.1097/01.hjh.0000125452.28861.f1)

Chistiakov DA, Grechko AV, Myasoedova VA, Melnichenko AA \& Orekhov AN 2018 The role of monocytosis and neutrophilia in atherosclerosis. Journal of Cellular and Molecular Medicine 22 1366-1382. (https://doi.org/10.1111/jcmm.13462)

Cirillo P, De Rosa S, Pacileo M, Gargiulo A, Angri V, Fiorentino I, Prevete N, Petrillo G, De Palma R, Leonardi A, et al. 2008 Human urotensin II induces tissue factor and cellular adhesion molecules expression in human coronary endothelial cells: an emerging role for urotensin II in cardiovascular disease. Journal of Thrombosis and Haemostasis 6 726-736. (https://doi.org/10.1111/j.15387836.2008.02923.x)

Cortvrindt C, Speeckaert R, Moerman A, Delanghe JR \& Speeckaert MM 2017 The role of interleukin-17A in the pathogenesis of kidney diseases. Pathology 49 247-258. (https://doi.org/10.1016/j. pathol.2017.01.003)

Coulouarn Y, Lihrmann I, Jegou S, Anouar Y, Tostivint H, Beauvillain JC, Conlon JM, Bern HA \& Vaudry H 1998 Cloning of the cDNA encoding the urotensin II precursor in frog and human reveals intense expression of the urotensin II gene in motoneurons of the spinal cord. PNAS 95 15803-15808. (https://doi.org/10.1073/ pnas.95.26.15803)

Deten A, Volz HC, Briest W \& Zimmer HG 2003 Differential cytokine expression in myocytes and non-myocytes after myocardial infarction in rats. Molecular and Cellular Biochemistry 242 47-55. (https://doi. org/10.1023/A:1021129410221)

Djordjevic T, BelAiba RS, Bonello S, Pfeilschifter J, Hess J \& Görlach A 2005 Human urotensin II is a novel activator of NADPH oxidase in human pulmonary artery smooth muscle cells. Arteriosclerosis, Thrombosis, and Vascular Biology 25 519-525. (https://doi. org/10.1161/01.ATV.0000154279.98244.eb)

Dong X, Ye X, Song N, Zhao J, Di B, Peng F, Tang C \& Ding W 2013 Urotensin II promotes the production of LTC4 in rat aortic adventitial fibroblasts through NF-кB-5-LO pathway by p38 MAPK and ERK activations. Heart and Vessels 28 514-523. (https://doi.org/10.1007/ s00380-012-0291-0)

Dorffel Y, Latsch C, Stuhlmuller B, Schreiber S, Scholze S, Burmester GR \& Scholze J 1999 Preactivation peripheral blood monocytes in patients with essential hypertension. Hypertension 34 113-117. (https://doi. org/10.1161/01.HYP.34.1.113)

Douglas SA, Tayara L, Ohlstein EH, Halawa N \& Giaid A 2002 Congestive heart failure and expression of myocardial urotensin II. Lancet 359 1990-1997. (https://doi.org/10.1016/S0140-6736(02)08831-1)
Dun SL, Brailoiu GC, Yang J, Chang JK \& Dun NJ 2001 Urotensin II-immunoreactivity in the brainstem and spinal cord of the rat. Neuroscience Letters 305 9-12. (https://doi.org/10.1016/S03043940(01)01804-3)

Elmadbouh I, Ali Soliman M, Abdallah Mostafa A \& Ahmed Heneish H 2017 The value of urotensin II in patients with left-sided rheumatic valvular regurgitagion. Egyptian Heart Journal 69 133-138. (https:// doi.org/10.1016/j.ehj.2016.09.006)

Garibotto G, Carta A, Picciotto D, Viazzi F \& Verzola D 2017 Toll-like receptor-4 signaling mediates inflammation and tissue injury in diabetic nephropathy. Journal of Nephrology 30 719-727. (https://doi. org/10.1007/s40620-017-0432-8)

Garoufi A, Drapanioti S, Marmarinos A, Askiti V, Mitsioni AJ, Mila M, Grigoriadou G, Georgakopoulos D, Stefanidis CJ \& Gourgiotis D 2017 Plasma urotensin II levels in children and adolescents with chronic kidney disease: a single-centre study. BMC Nephrology 18 113. (https:// doi.org/10.1186/s12882-017-0530-9)

Gendron G, Simard B, Gobeil F, Sirois P, D'Orléans-Juste P \& Regoli D 2004 Human urotensin-II enhance extravasation in specific vascular districts in Wistar rats. Canadian Journal of Physiology and Pharmacology 82 16-21. (https://doi.org/10.1139/y03-122)

Goldberg AA, Joung KB, Mansuri A, Kang Y, Echavarria R, Nikolajev L, Sun Y, Yu JJ, Laporte SA, Schwertani A, et al. 2016 Oncogenic effects of urotensin-II in cells lacking tuberous sclerosis complex-2. Oncotarget 7 61152-61165. (https://doi.org/10.18632/oncotarget.10748)

Guiteras R, Flaquer M \& Cruzado JM 2016 Macrophage in chronic kidney disease. Clinical Kidney Journal 9 765-771. (https://doi.org/10.1093/ $\mathrm{ckj} / \mathrm{sfw096)}$

Hassan GS, Douglas SA, Ohlstein EH \& Giaid A 2005 Expression of urotensin-II in human coronary atherosclerosis. Peptides $\mathbf{2 6}$ 2464-2472. (https://doi.org/10.1016/j.peptides.2005.05.028)

He WY, Bai Q, A LT, Tang CS \& Zhang AH 2015 Irisin levels are associated with urotensin II levels in diabetic patients. Journal of Diabetes Investigation 6 571-576. (https://doi.org/10.1111/jdi.12331)

Ishihata A, Ogaki T, Aita T \& Katano Y 2005 Role of prostaglandins in urotensin II-induced vasodilatation in the coronary arteries of aged rats. European Journal of Pharmacology 523 119-126. (https://doi. org/10.1016/j.ejphar.2005.09.018)

Jani PP, Narayan H \& Ng LL 2013 The didderential extraction and immunoluminometric assay of urotensin II and urotensin-related peptide in heart failure. Peptides 40 72-76. (https://doi.org/10.1016/j. peptides.2012.12.014)

Johns DG, Ao Z, Naselsky D, Herold CL, Maniscalco K, Sarov-Blat L, Steplewski K, Aiyar N \& Douglas SA 2004 Urotensin-II-mediated cardiomyocyte hypertrophy: effect of receptor antagonism and role of inflammatory mediators. Naunyn-Schmiedeberg's Archives of Pharmacology 370 238-250. (https://doi.org/10.1007/s00210-0040980-z)

Jumaah S, Celekli A \& Sucu M 2018 The role of human urotensin-II in patients with hypertrophic cardiomyopathy. Journal of Immunoassay and Immunochemistry 39 150-162. (https://doi.org/10.1080/15321819 .2017.1344130)

Kawaguchi Y, Ono T, Kudo M, Kushikata T, Hashiba E, Yoshida H, Kudo T, Furukawa K, Douglas SA \& Hirota K 2009 The effects of benzodiazepines on urotensin II-stimulated norepinephrine release from rat cerebrocortical slices. Anesthesia and Analgesia 108 1177-1181. (https://doi.org/10.1213/ane.0b013e3181981faa)

Khoshi A, Mohammadi A \& Najar A 2014 Effect of urotensin II on apolipoprotein B100 and apolipoprotein A-1 expression in HepG2 cell line. Advanced Biomedical Research 3 22. (https://doi. org/10.4103/2277-9175.124661)

Kim TH, Lee DG, Kim YA, Kim YA, Lee BH, Yi KY \& Jung YS 2017 A novel urotensin II receptor antagonist, KR-36996 inhibits smooth muscle proliferation through ERK/ROS pathway. Biomolecules and Therapeutics 25 308-314. (https://doi.org/10.4062/biomolther.2016.219) https://joe.bioscientifica.com https://doi.org/10.1530/JOE-18-0505 (c) 2019 Society for Endocrinology Published by Bioscientifica Ltd. Printed in Great Britain 
Koelwyn GJ, Corr EM, Erbay E \& Moore KJ 2018 Regulation of macrophage immunometabolism in atherosclerosis. Nature Immunology 19 526-537. (https://doi.org/10.1038/s41590-018-0113-3)

Lacza Z \& Busija DW 2006 Urotensin-II is a nitric oxide-dependent vasodilator in the pial arteries of the newborn pig. Life Sciences $\mathbf{7 8}$ 2763-2766. (https://doi.org/10.1016/j.lfs.2005.11.002)

Langham RG \& Kelly DJ 2013 Urotensin II and the kidney. Current Opinion in Nephrology and Hypertension 22 107-112. (https://doi. org/10.1097/MNH.0b013e32835b6d57)

Lee JC, Laydon JT, McDonnell PC, Gallagher TF, Kumar S, Green D, McNulty D, Blumenthal MJ, Heys JR, Landvatter SW, et al. 1994 A protein kinase involved in the regulation of inflammatory cytokine biosynthesis. Nature 372 739-746. (https://doi. org/10.1038/372739a0)

Lee CY, Tsai YT, Loh SH, Liu JC, Chen TH, Chao HH, Cheng TH \& Chen JJ 2014 Urotensin II induces interleukin 8 expression in human umbilical vein endothelial cells. PLoS One 9 e90278. (https://doi. org/10.1371/journal.pone.0090278)

Lee JH, Park BK, Oh KS, Yi KY, Lim CJ, Seo HW \& Lee BH 2016 A urotensin II receptor antagonist, KR36676, decreases vascular remodeling and inflammation in experimental pulmonary hypertension. International Immunopharmacology 40 196-202. (https:// doi.org/10.1016/j.intimp.2016.09.002)

Leifeld L, Clemens C, Heller J, Trebicka J, Sauerbruch T \& Spengler U 2010 Expression of urotensin II and its receptor in human liver cirrhosis and fulminant hepatic failure. Digestive Diseases and Sciences 55 1458-1464. (https://doi.org/10.1007/s10620-009-0875-4)

Li X \& Chen N 2013 Management of crescentic glomerulonephritis: what are the recent advances? Contributions to Nephrology 181 229-239. (https://doi.org/10.1159/000348479)

Li JJ, Fang CH \& Hui RT 2005 Is hypertension an inflammatory disease? Medical Hypotheses 64 236-240. (https://doi.org/10.1016/j. mehy.2004.06.017)

Li Y, Zhao S, Wang Y, Chen Y, Lin Y, Zhu N, Zheng H, Wu M, Cheng D, Li Y, et al. 2014 Urotensin II promotes atherosclerosis in cholesterolfed rabbits. PLoS One 9 e95089. (https://doi.org/10.1371/journal. pone.0095089)

Li YY, Shi ZM, Yu XY, Feng P \& Wang XJ 2016 Urotensin II-induced insulin resistence is mediated by NADPH oxidase-derived reactive oxygen species in HepG2 cells. World Journal of Gastroenterology 22 5769-5779. (https://doi.org/10.3748/wjg.v22.i25.5769)

Li YY, Shi ZM, Yu XT, Feng P \& Wang XJ 2017 The effects of urotensin II on migration and invasion are mediated by NADPH oxidasederived reactive oxyen species through the c-Jun N-terminal kinase pathway in human hepatoma cells. Peptides 88 106-114. (https://doi. org/10.1016/j.peptides.2016.12.005)

Liang DY, Liu LM, Ye CG, Zhao L, Yu FP, Gao DY, Wang YY, Yang ZW \& Wang YY 2013 Inhibition of UII/UTR system relieves acute inflammation of liver through preventing activation of NF- $\mathrm{B}$ pathway in ALF mice. PLoS One 8 e64895. (https://doi.org/10.1371/ journal.pone.0064895)

Lichtman SN, Wang J \& Lemasters JJ 1998 Lipopolysaccharide stimulated TNF-alpha release from cultured rat Kupffer cells: sequence of intracellular signaling pathways. Journal of Leukocyte Biology 64 368-372. (https://doi.org/10.1002/jlb.64.3.368)

Liu DG, Wang J, Zhang ZT \& Wang Y 2009 The urotensin II antagonist SB-710411 arrests fibrosis in CCL4 cirrhotic rats. Molecular Medicine Reports 2 953-961. (https://doi.org/10.3892/mmr_00000198)

Liu LM, Liang DY, Ye CG, Tu WJ \& Zhu T 2015a The UII/UT system mediates upregulation of proinflammatory cytokines through p38 MAPK and NF-кB pathway in LPS-stimulated Kupffer cells. PLoS One 10 e0121383. (https://doi.org/10.1371/journal.pone.0121383)

Liu LM, Zhao L, Liang DY, Yu FP, Ye CG, Tu WJ \& Zhu T $2015 b$ Effects of urotensin-II on cytokines in early acute liver failure in mice. World Journal of Gastroenterology 21 3239-3244. (https://doi.org/10.3748/ wjg.v21.i11.3239)
Liu DG, Chen J, Wang HX \& Li BX $2016 a$ Increased expression of urotensin II is associated with poor prognosis in hepatocellular carcinoma. Oncology Letters 12 4961-4968. (https://doi.org/10.3892/ ol.2016.5344)

Liu LM, Tu WJ, Zhu T, Wang XT, Tan ZL, Zhong H, Gao DY \& Liang DY $2016 b$ IRF3 is an important molecule in the UII/UT system and mediates immune inflammatory injury in acute liver failure. Oncotarget 7 49027-49041. (https://doi.org/10.18632/ oncotarget.10717)

Loirand G, Rolli-Derkinderen M \& Pacaud P 2008 Urotensin II and atherosclerosis. Peptides 29 778-782. (https://doi.org/10.1016/j. peptides.2007.08.024)

Maguire JJ, Kuc RE \& Davenport AP 2000 Orphan-receptor ligand human urotensin II: receptor localization in human tissues and comparison of vasoconstrictor responses with endothelin-1. British Journal of Pharmacology 131 441-446. (https://doi.org/10.1038/sj.bjp.0703601)

Maguire JJ, Kuc RE, Wiley KE, Kleinz MJ \& Davenport AP 2004 Cellular distribution of immunoreactive urotensin-II in human tissues with evidence of increased expression in atherosclerosis and a greater constrictor response of small compared to large coronary arteries. Peptides 25 1767-1774. (https://doi.org/10.1016/j. peptides.2004.01.028)

Matsushita M, Shichiri M, Imai T, Iwashina M, Tanaka H, Takasu N \& Hirata Y 2001 Co-expression of urotensin II and its receptor (GFR14) in human cardiovascular and renal tissues. Journal of Hypertension 19 2185-2190. (https://doi.org/10.1097/00004872200112000-00011)

Miteva K, Madonna R, De Caterina R \& Van Linthout S 2018 Innate and adaptive immunity in atherosclerosis. Vascular Pharmacology $\mathbf{1 0 7}$ 67-77. (https://doi.org/10.1016/j.vph.2018.04.006)

Ni X, Wang A, Zhang L, Shan LY, Zhang HC, Li L, Si JQ, Luo J, Li XZ \& Ma KT 2017 Up-regulation of gap junction in peripheral blood T lymphocytes contributes to the inflammatory response in essential hypertension. PLoS One 12 e0184773. (https://doi.org/10.1371/ journal.pone.0184773)

Nothacker HP, Wang Z, McNeill AM, Saito Y, Merten S, O’Dowd B, Duckles SP \& Civelli O 1999 Identification of the natural ligand of an orphan G-protein-coupled receptor involved in the regulation of vasoconstriction. Nature Cell Biology 1 383-385. (https://doi. $\operatorname{org} / 10.1038 / 14081)$

Oh KS, Lee JH, Yi KY, Lim CJ, Park BK, Seo HW \& Lee BH 2017 A novel urotensin II receptor antagonist, KR-36996, improved cardiac function and attenuated cardiac hypertrophy in experimental heart failure. European Journal of Pharmacology 799 94-102. (https://doi. org/10.1016/j.ejphar.2017.02.003)

Onat AM, Turkbeyler IH, Pehlivan Y, Demir T, Kaplan DS, Taysi S, Ceribasi AO, Tutar E \& Kisacik B 2012 The efficiency of a urotensin II antagonist in an experimental lung fibrosis model. Inflammation 35 1138-1143. (https://doi.org/10.1007/s10753-011-9421-6)

Park CH, Lee JH, Lee MY, Lee JH, Lee BH \& Oh KS 2016 A novel role of G protein-coupled receptor kinase 5 in urotensin II-stimulated cellular hypertrophy in H9c2UT cells. Molecular and Cellular Biochemistry $\mathbf{4 2 2}$ 151-160. (https://doi.org/10.1007/s11010-016-2814-y)

Peng H, Zhang M, Cai X, Olofindayo J, Tan A \& Zhang Y 2013 Association between human urotensin II and essential hypertension - a 1:1 matched case-control study. PLoS One 8 e81764. (https://doi. org/10.1371/journal.pone.0081764)

Rahimi R, Karimi J, Khodadadi I, Tayebinia H, Kheiripour N, Hashemnia M \& Goli F 2018 Silymarin ameliorates expression of urotensin II (UII) and its receptor (UTR) and attenuates toxic oxidative stress in the heart of rats with type 2 diabetes. Biomedicine and Pharmacotherapy 101 244-250. (https://doi.org/10.1016/j. biopha.2018.02.075)

Ramadori G \& Armbrust T 2001 Cytokines in the liver. European Journal of Gastroenterology and Hepatology 13 777-784. (https://doi. org/10.1097/00042737-200107000-00004) 
Rodriguez-Moyano M, Diaz I, Dionisio N, Zhang X, Avila-Medina J, Calderón-Sánchez E, Trebak M, Rosado JA, Ordóñez A \& Smani T 2013 Urotensin-II promotes vascular smooth muscle cell proliferation through store-operated calcium entry and EGFR transactivation. Cardiovascular Research 100 297-306. (https://doi.org/10.1093/cvr/ cvt196)

Ross B, McKendy K \& Giaid A 2010 Role of urotensin II in health and disease. American Journal of Physiology. Regulatory, Integrative and Comparative Physiology 298 R1156-R1172. (https://doi.org/10.1152/ ajpregu.00706.2009)

Schmid-Schönbein GW, Seiffge D, DeLano FA, Shen K \& Zweifach BW 1991 Leukocyte counts and activation in spontaneously hypertensive and normotensive rats. Hypertension 17 323-330. (https://doi. $\operatorname{org} / 10.1161 / 01 . H Y P .17 .3 .323)$

Segain JP, Rolli-Derkinderen M, Gervois N, Raingeard de la Blétière D, Loirand G \& Pacaud P 2007 Urotensin II is a new chemotactic factor for UT receptor-expressing monocytes. Journal of Immunology $\mathbf{1 7 9}$ 901-909. (https://doi.org/10.4049/jimmunol.179.2.901)

Shenouda A, Douglas SA, Ohlstein EH \& Giaid A 2002 Localization of urotensin-II immunoreactivity in normal human kidneys and renal carcinoma. Journal of Histochemistry and Cytochemistry $\mathbf{5 0}$ 885-889. (https://doi.org/10.1177/002215540205000702)

Small HY, Migliarino S, Czesnikiewicz-Guzik M \& Guzik TJ 2018 Hypertension: focus on autoimmunity and oxidative stress. Free Radical Biology and Medicine 125 104-115. (https://doi.org/10.1016/j. freeradbiomed.2018.05.085)

Song W, Abdel-Razik AE, Lu W, Ao Z, Johns DG, Douglas SA, Balment RJ \& Ashton N 2006 Urotensin II and renal function in the rat. Kidney International 69 1360-1368. (https://doi.org/10.1038/sj.ki.5000290)

Soni H \& Adebiyi A 2017 Urotensin II-induced store-operated Ca2+ entry contributes to glomerular mesangial cell proliferation and extracellular matrix protein production under high glucose conditions. Scientific Reports 7 18049. (https://doi.org/10.1038/ s41598-017-18143-x)

Su JL, Ao Z, Aiyar NV, Ellis B, Martin JD, Douglas SA \& Kull FC Jr 2003 Production and characterization of monoclonal antibodies against the vasoconstrictive peptide human urotensin-II. Hybridoma and Hybridomics 22 377-382. (https://doi.org/10.1089/153685903771797075)

Su H, Lei CT \& Zhang C 2017 Interleukin-6 signaling pathway and its role in kidney disease: an update. Frontiers in Immunology 8 405. (https:// doi.org/10.3389/fimmu.2017.00405)

Sun C, Duan D, Li B, Qin C, Jia J, Wang B, Dong H \& Li W 2013 UII and UT in grouper: cloning and effects on the transcription of hormones related to growth control. Journal of Endocrinology 220 35-48. (https:// doi.org/10.1530/JOE-13-0282)

Sun HJ, Ren XS, Xiong XQ, Chen YZ, Zhao MX, Wang JJ, Zhou YB, Han Y, Chen Q, Li YH, et al. 2017 NLRP3 inflammasome activation contributes to VSMC phenotypic transformation and proliferation in hypertension. Cell Death and Disease 8 e3074. (https://doi. org/10.1038/cddis.2017.470)

Tabur S, Korkmaz H, Eren MA, Oğuz E, Sabuncu T \& Aksoy N 2015 Urotensin-II level and its association with oxidative stress in early diabetic nephropathy. Journal of Diabetes and its Complications 29 115-119. (https://doi.org/10.1016/j.jdiacomp.2014.07.011)

Tomiyama S, Nakamachi T, Uchiyama M, Matsuda K \& Konno N 2015 Urotensin II upregulates migration and cytokine gene expression in leukocytes of the African clawed frog, Xenopus laevis. General and Comparative Endocrinology 216 54-63. (https://doi.org/10.1016/j. ygcen.2015.04.009)

Torre-Amione G, Vooletich MT \& Farmer JA 2000 Role of tumour necrosis factor-alpha in the progression of heart failure: therapeutic implications. Drugs 59 745-751. (https://doi.org/10.2165/00003495200059040-00002)

Totsune K, Takahashi K, Arihara Z, Sone M, Ito S \& Murakami O 2003 Increased plasma urotensin II levels in patients with diabetes mellitus. Clinical Science 104 1-5. (https://doi.org/10.1042/cs1040001)
Tsutsui H \& Nishiguchi S 2014 Importance of Kupffer cells in the development of acute liver injuries in mice. International Journal of Molecular Sciences 15 7711-7730. (https://doi.org/10.3390/ ijms15057711)

Ugan RA, Cadirci E, Halici Z, Toktay E \& Cinar I 2018 The role of urotensin-II and its receptor in sepsis-induced lung injury under diabetic conditions. European Journal of Pharmacology 818 457-469. (https://doi.org/10.1016/j.ejphar.2017.11.011)

Vaudry H, Do Rego JC, Le Mevel JC, Chatenet D, Tostivint H, Fournier A, Tonon MC, Pelletier G, Conlon JM \& Leprince J 2010 Urotensin II, from fish to human. Annals of the New York Academy of Sciences 1200 53-66. (https://doi.org/10.1111/j.1749-6632.2010.05514.x)

Wang H, Dong K, Xue X, Feng P \& Wang X 2011 Elevated expression of urotensin II and its receptor in diethylnitrosamine-mediated precancerous lesions in rat liver. Peptides 32 382-387. (https://doi. org/10.1016/j.peptides.2010.10.032)

Wang HX, Wu XR, Yang H, Yin CL, Shi LJ \& Wang XJ 2013 Urotensin II inhibits skeletal muscle glucose transport signaling pathways via the NADPH oxidase pathway. PLoS One 8 e76796. (https://doi. org/10.1371/journal.pone.0076796)

Wang Y, Wu JF, Tang YY, Zhang M, Li Y, Chen K, Zeng MY, Yao F, Xie W, Zheng XL, et al. 2014 Urotensin II increases foam cell formation by repressing ABCA1 expression through the ERK/ NF-кB pathway in THP-1 macrophages. Biochemical and Biophysical Research Communications 452 998-1003. (https://doi.org/10.1016/j. bbrc.2014.09.030)

Wang YH \& Zhang YG 2017 Kidney and innate immunity. Immunology Letters 183 73-78. (https://doi.org/10.1016/j.imlet.2017.01.011)

Wang DX, Pan YQ, Liu B \& Dai L 2018 Cav-1 promotes atherosclerosis by activating JNK-associated signaling. Biochemical and Biophysical Research Communications 503 513-520. (https://doi.org/10.1016/j. bbrc.2018.05.036)

Watanabe T, Suguro T, Kanome T, Sakamoto Y, Kodate S, Hagiwara T, Hongo S, Hirano T, Adachi M \& Miyazaki A 2005 Human urotensin II accelerates foam cell formation in human monocyte-derived macrophages. Hypertension 46 738-744. (https://doi.org/10.1161/01. HYP.0000184226.99196.b5)

Watanabe T, Arita S, Shiraishi Y, Suguro T, Sakai T, Hongo S \& Miyazaki A 2009 Human urotensin II promotes hypertension and atherosclerotic cardiovascular diseases. Current Medicinal Chemistry 16 550-563. (https://doi.org/10.2174/092986709787458515)

Wheeler MD 2003 Endotoxin and Kupffer cell activation in alcoholic liver disease. Alcohol Research and Health 27 300-306.

Wu YQ, Song Z, Zhou CH, Xing SH, Pei DS \& Zheng JN 2010 Expression of urotensin II and its receptor in human lung adenocarcinoma A549 cells and the effect of urotensin II on lung adenocarcinoma growth in vitro and in vivo. Oncology Reports 24 1179-1184.

Xu J, Han Q, Shi H, Liu W, Chu T \& Li H 2017 Role of PKA in the process of neonatal cardiomyocyte hypertrophy induced by urotensin II. International Journal of Molecular Medicine 40 499-504. (https://doi. org/10.3892/ijmm.2017.3038)

Yamauichi-Takihara Y \& Kishimoto T 2000 Cytokines and their receptors in cardiovascular diseases-role of gp130 signalling pathway in cardiac myocyte growth and maintenance. International Journal of Experimental Pathology 81 1-16. (https://doi.org/10.1046/j.13652613.2000.00139.x)

Yang Y, Zhang J, Chen X, Wu T, Xu X, Cao G, Li H \& Li Y 2016 UII/ GPR14 is involved in NF-кB-mediated colonic inflammation in vivo and in vitro. Oncology Reports 36 2800-2806. (https://doi.org/10.3892/ or.2016.5069)

Yoshimura A, Naka T \& Kubo M 2007 SOCS proteins, cytokine signalling and immune regulation. Nature Reviews. Immunology 7 454-465. (https://doi.org/10.1038/nri2093)

You Z, Genest J Jr, Barrette PO, Hafiane A, Behm DJ, D'Orleans-Juste P \& Schwertani AG 2012 Genetic and pharmacological manipulation of urotensin II ameliorate the metabolic and atherosclerosis sequalae in 
mice. Arteriosclerosis, Thrombosis, and Vascular Biology 32 1809-1816. (https://doi.org/10.1161/ATVBAHA.112.252973)

You Z, Al Kindi H, Abdul-Karim A, Barrette PO \& Schwertani A 2014 Blocking the urotensin II receptor pathway ameliorates the metabolic syndrome and improves cardiac function in obese mice. FASEB Journal 28 1210-1220. (https://doi.org/10.1096/fj.13-236471)

Yu L \& Feng Z 2018 The role of toll-like receptor signaling in the progression of heart failure. Mediators of Inflammation 20189874109. (https://doi.org/10.1155/2018/9874109)

Yu XT, Wang PY, Shi ZM, Dong K, Feng P, Wang HX \& Wang XJ 2014 Up-regulation of urotensin II and its receptor contributes to human hepatocellular carcinoma growth via activation of the PKC, ERK1/2, and p38 MAPK signaling pathways. Molecules 19 20768-20779. (https://doi.org/10.3390/molecules191220768)

Yu XT, Wang PY, Shi ZM, Dong K, Feng P, Wang HX \& Wang XJ 2015 Urotensin-II-mediated reactive oxyen species generation via NAPDH oxidase pathway contributes to hepatic oval cell proliferation. PLOS One 10 e0144433. (https://doi.org/10.1371/journal.pone.0144433)

Zhang AY, Chen YF, Zhang DX, Yi FX, Qi J, Andrade-Gordon P, de Garavilla L, Li PL \& Zou AP 2003 Urotensin II is a nitric oxidedependent vasodilator and natriuretic peptide in the rat kidney. American Journal of Physiology. Renal Physiology 285 F792-F798. (https://doi.org/10.1152/ajprenal.00342.2002)

Zhang Y, Bauersachs J \& Langer HF 2017 Immune mechanisms in heart failure. European Journal of Heart Failure 19 1379-1389. (https://doi. org/10.1002/ejhf.942)

Zhao J, Ding W, Song N, Dong X, Di B, Peng F \& Tang C 2013a Urotensin II-induced collagen synthesis in cultured smooth muscle cells from rat aortic media and a possible involvement of transforming growth factor- $\beta 1 / \mathrm{Smad} 2 / 3$ signaling pathway. Regulatory Peptides 182 53-58. (https://doi.org/10.1016/j.regpep.2012.12.006)

Zhao J, Yu QX, Kong W, Gao HC, Sun B, Xie YQ \& Ren LQ $2013 b$ The urotensin II receptor antagonist, urantide, protects against atherosclerosis in rats. Experimental and Therapeutic Medicine 5 1765-1769. (https://doi.org/10.3892/etm.2013.1052)

Zhao J, Xie LD, Song CJ, Mao XX, Yu HR, Yu QX, Ren LQ, Shi Y, Xie YQ, Li Y, et al. 2014 Urantide improves atherosclerosis by controlling C-reactive protein, monocyte chemotactic protein-1 and transforming growth factor- $\beta$ expression in rats. Experimental and Therapeutic Medicine 7 1647-1652. (https://doi.org/10.3892/ etm.2014.1654)

Zhao S, Li Y, Gao S, Wang X, Sun L, Cheng D, Bai L, Guan H, Wang R, Fan J, et al. 2015 Autocrine human urotensin II enhances macrophage-derived foam cell formation in transgenic rabbits. BioMed Research International 2015 843959. (https://doi. org $/ 10.1155 / 2015 / 843959)$

Zhou CH, Wan YY, Chu XH, Song Z, Xing SH, Wu YQ \& Yin XX 2012 Urotensin II contributes to the formation of lung adenocarcinoma inflammatory microenvironment through the NF-кB pathway in tumor-bearing nude mice. Oncology Letters 4 1259-1263. (https://doi. org/10.3892/ol.2012.932)

Zhu L, Sui L, Wu S, Wang L, Fu J \& Wang X 2015 Association between essential hypertension and three vasoactive peptides, urotensin II, endothelin and adrenomedullin. Clinical and Experimental Hypertension 37 604-608. (https://doi.org/10.3109/10641963.2015.1 047940)

Received in final form 21 December 2018

Accepted 2 January 2019

Accepted Preprint published online 2 January 2019 (c) 2019 Society for Endocrinology Published by Bioscientifica Ltd. 